DOI: 10.17707/AgricultForest.62.1.18

\begin{abstract}
Viktoria LOVINSKA, Svitlana SYTNYK, Mykola KHARYTONOV, Irina LOZA ${ }^{I}$
\end{abstract}

\title{
FEATURES OF PINE STANDS FUNCTION IN DNIEPER NORTH STEPPE, UKRAINE
}

\begin{abstract}
SUMMARY
The article is devoted to distribution of Pinus sylvestris stands areas within North Steppe on the basic of forestry biometric indexes. The research objective was analysis of current state of Pinus sylvestris stands within Dnieper North Steppe on the main silvicultural and forest inventory parameters. The forest stands within Steppe zone are formed under conditions extremely unfavorable for arboreal plants growth. Occupying a very wide area, Pinus sylvestris has a large number of ecological forms, and it is both tolerant to low and high temperatures, it is winter-hardy and low-demanding to soil fertility and moisture. It was noted the irregular age structure in pine plantations under regional condition. Area of Pinus sylvestris stands within North Dnieper Steppe is 21472 ha with the total growing stock $45711 \mathrm{~m} 3 \cdot$ ha-1. According to age structure, majority of the stands from Pinus sylvestris were middle-aged within the studied region, with the greatest representation in the IV-VI age classes. Pinus sylvestris distribution by structure rate showed significant dominance of pure stands. Pinus sylvestris It was established the prevailing types of site forest conditions on the basis of the edaphic factors (soil fertility and humidity). Pinus sylvestris forests mainly formed under pine mixed forest site type, in dry and mesic hygrotopes. The largest area of the analyzed species was occupied by stands of II and above forest capacity classes. The obtained results show predominance of high-productive pine stands within studied area. It was found that the maximum area of pine stands have high relative density.
\end{abstract}

Keywords: forest fund, Pinus sylvestris, growing stock, indexes of forest biometrics

\section{INTRODUCTION}

In recent times, particularly after the United Nations Conference on Environment and Development 1992 (UNCED), there have taken place a substantial changes in priorities of relationships between individual and forest, which involve transition from the use of forest as a resource to the management

\footnotetext{
1 Viktoria Lovinska , Svitlana Sytnyk, Mykola Kharytonov,(corresponding author: myrt74@mail.ru,glub@ukr.net) ,Dnipropetrovsk State Agrarian and Economic University,Voroshylovast., 25, 49060, Dnipropetrovsk, UKRAINE, Irina Loza, 2Oles Honchar Dnipropetrovsk National University, Gagarin ave., 72, 49000, Dnipropetrovsk, UKRAINE Paper presented at the $6^{\text {th }}$ International Scientific Agricultural Symposium "AGROSYM 2015". Notes: The authors declare that they have no conflicts of interest. Authorship Form signed online.
} 
of processes within forest ecosystems. The most important criteria for sustainable forest management are considered to be support and preservation of forests productive capacity, their protective and social functions, and biodiversity (Hensiruk, 1992; Casparsen and Pacala, 2001; Scherer-Lorenzen et al., 2005) because dramatic changes associated with human activities on environment effect negatively on the stands condition and functioning (Bormann, 1985; FAO, 1993). As a major component of forests, arboreal plants reflect the overall status of forest ecosystems, the features of their functioning and the main trends of their development. These issues were investigated by the authors in scientific publications (Loza and Nazarenko, 2006; Bezrodnova et al., 2013; Lovinska, 2014; Sytnyk et al., 2015).

It is known that in the Steppe zone forest stands are formed under conditions extremely unfavorable for arboreal plants growth. Only a few species are able to adapt to the complex of stress factors typical for this natural area. One of them is Scots pine (Pinus sylvestris L.), is known for its high resistance (Belgard, 1971; Vakuliuk, 2006; Siryk, 1991; Sychev, 2011). Significant distribution and penetration of single populations outside the forest zone are proved by high adaptive capacity of such species. Occupying a very wide area, Scots pine has a large number of ecological forms, therefore, this species is both tolerant to low and high temperatures, it is winter-hardy and low-demanding to soil fertility and moisture. Usage the not scientifically substantiated methods of forest management had led to deterioration in the forest stands quality, loss of their environmental-forming, resource, and recreational functions. For this reason, it is very important to obtain the complete and reliable information regarding status of forest-forming species within the stands for effective management and conservation of forest ecological and social functions (Alekseyev, 2003; Gulchak, 2011). The forest management process should begin with investigation of the forest stand characteristics.

The state and productivity of such characteristics are influenced by a complex of factors, first of all, age of forest-forming species, forest site condition, capacity, and stand density. As the research objective, it was analysis of the current state of Scots pine stands within Dnieper North (ravine) Steppe on their main silvicultural and forest inventory parameters.

\section{MATERIAL AND METHODS}

The objects of the survey were pine stands of North Dnieper Steppe within the Dnipropetrovsk oblast. The survey of silvicultural taxational characters in pine stands was performed using information of stratum database "Ukrderzhlesproekt" and conventional methods of forest inventory (Anuchin, 1982; Gulchak, 2011) in 2009-2014. On the basis of this database, it was processed 4790 stratums in accordance to the relevant indexes within the existing age groups of trees. The analysis was subjected to such characteristics of Scots pine stands as forest type, composition, age of stand, mean height and diameter, timber resource, forest capacity, and relative density. 
The classification schemes of trophotopes and gygrotopes is based on the edaphic factors, such as soil fertility and humidity. Soil fertility is characterized by trophogenic sequence and denoted by the letters A, B, C, and D. These individual units of trophogenic sequence called trophotopes. Each trophotope is represented by the forest site with equal soil fertility within self boundaries, distinguished from the next by one gradation (Belgard, 1971). Trophotope "A", "bor" or pure pine forest, indicate very poor soil conditions, predominantly with sandy soil, sometimes loamy sands with a short rhizosphere zone; gritty consistency stipulate their poorness. Trophotope "B", "subor" or mixed pine forest is characterized by relatively poor soils. It is represented by loamy sand or sandy soil with thin sandy-loam or loamy layers, or with heavy layers of that at a considerable depth. Trophotope "C", "sugrud" or oak mixed forest has a relatively rich habitat conditions. Soils are represented by sandy-loam, sometimes sand with layers of loam and sandy-loam, or denuded shallow grey forest soil, sometimes brown soil with the little humus horizon, skeletal, derived from volcanic rocks and sandstones. Trophotope "D", "grud" or oak pure forest has the most fertile habitat conditions. The soils are loam with the heavy (greater than $0.8 \mathrm{~m}$ ) rhizosphere, more rarely sandy and sandy-loam soils with the layers of loam and clay, available to plant roots. Sometimes the sandy and sandy-loam soils occur with shallow horizon of flow "mineralized" groundwater.

Whereas, the trophotopes are divided by six gygrogene sequences: gygrotopes with indicators of soil moisture 0 to 5 . Gygrotopes of 0 range respond to very dry (xerophilic) conditions; 1 - dry (meso-xerophilic); 2 - mesic (mesophilic); 3 - mesic-wet (meso-gygrophilic); 4 - wet (gygrophilic); 5 swamp (ultragygrophilic).

According to the classification scheme, each site of forest is characterized by two classification units: trophotope and hygrotope. In the surveyed forest stands we selected 16 sampling units for Scots pine in existing grades of trophotopes and hygrotopes within stands of different ages. The delimitation of sampling units was carried out instrumentally with surface marking and binding to net of rides. The size of sampling units was ranged from 0.25 to 0.5 hectares. Within the sampling units it was determined the total growing stock with the model trees by way of step representation. Model trees were selected for each level of thickness. Work on the sampling units was performed in the following order:

1) complete tree enumeration;

2) determination of the mean diameter of the stands with usage of average cross-sectional area according to tally sheet, by dividing the sum of basal areas on the total number of trees within the forest stand;

3) selection of three medium-size and shape sample trees in the each level of thickness;

4) measurement of diameter of the sample tree accurate to $0.1 \mathrm{~cm}$; 
5) measurement of height of the sample tree accurate to $0.1 \mathrm{~m}$;

6) cutting of the sample trees;

7) determination of volume of the sample tree by the formula:

$\mathrm{V}_{\mathrm{aver}}=\mathrm{g}_{\mathrm{aver}} \times \mathrm{h}_{\mathrm{aver}} \times \mathrm{f}_{\mathrm{aver}}$

where: $g_{\text {aver }}$ - cross-sectional area of the average sample tree; $h_{\text {aver }}-$ average height of the average sample tree, $f_{\text {aver }}-$ form factor of the average sample tree;

8) determination of stock in the sampling unit according to the formula:

$\mathrm{M}=\mathrm{V}_{\text {aver }} \times \mathrm{N}$

where: $\mathrm{M}$ - growing stock, $\mathrm{V}_{\text {aver }}$ - volume of the average sample tree, $\mathrm{N}-$ number of trees within the stand.

Values of the growing stock obtained on the sampling unit for investigated tree species was transferred on 1 ha according to the formula:

$\mathrm{M}={ }_{\text {Msamp.un }} \times \mathrm{F}_{\text {conv }}$

by multiplying it on the conversion factor $F_{\text {conv }}=1 \mathrm{ha} / \mathrm{S}_{\text {sampl.u}}$.

According to the materials of forest management, there were found the area of Scots pine stands belonging to a particular age class, and the total growing stock of this species within surveyed areas. The age class Scots pine was 10 years. In the stands of the same age, determination of dependence of growing stock formation on the type of trophotope and hygrotope was determined by usage of the average growing stock by the formula:

$\mathrm{M}_{\text {aver }}=\mathrm{M}_{\text {total age cl }} / \mathrm{S}_{\text {stand age cl }}$

where $\mathbf{M}_{\text {total age cl }}$ is the total growing stock in the same age class stands, $\mathrm{S}_{\text {stand age cl }}$ is the area of the stand of given age class.

\section{RESULTS AND DISCUSSION}

According to our silvicultural and forest inventory analysis, the total area of Scots pine plantations within North Dnieper Steppe was 21472.9 ha with a growing stock $4571 \mathrm{~m}^{3} \cdot \mathrm{ha}^{-1}$. The native pine stands occupy the area of $3693.8 \mathrm{ha}$ $(17.2 \%)$, while artificial pine forest stands were located on 17779.1 ha $(82.8 \%$ respectively) of the pine plantations total area. Age of stands has a great biological and economic importance; it is associated with growth stages of the stands. In forestry, it is known the "normal forest" concept, which is characterized by a uniform distribution of stands by age groups. It is the most favorable from the standpoint of economic benefit. According to actual data, it was established that the Scots pine stands were considerable asymmetric within the age groups. The middle-aged stands were predominated in $58.5 \%$ as well as the young stands occupied $32.7 \%$ of the total area (Table 1). The mean age of dominant group was 60 years, and the average young group age was 23 years, with average growing stock 292 and $92 \mathrm{~m}^{3} \cdot \mathrm{ha}^{-1}$ respectively. Amount of the pine stands area in other age groups was not exceeding $10 \%$. 
Tabele 1. The pine stands distribution, stock and average valuation indexes according to age groups

\begin{tabular}{|c|l|l|l|l|l|l|l|l|}
\hline \multirow{2}{*}{ Age groups } & \multicolumn{3}{|c|}{ Area } & \multicolumn{3}{c|}{ Growing stock } & \multicolumn{3}{c|}{ Average parameters } \\
\cline { 2 - 9 } & ha & $\%$ & ths. ${ }^{3}$ & $\%$ & $\mathrm{~m}^{3} / \mathrm{ha}$ & $\mathrm{D}, \mathrm{cm}$ & $\mathrm{H}, \mathrm{m}$ & A, yrs \\
\hline Young-age & 7037.1 & 32.7 & 768.1 & 16.7 & 92 & 9.9 & 8.3 & 23 \\
\hline Middle-age & 12556. & 58.5 & 3353.8 & 73.4 & 292 & 25.2 & 20.7 & 60 \\
\hline Maturing & 1344.6 & 6.3 & 341.8 & 7.5 & 273 & 34.0 & 23.7 & 82 \\
\hline Mature & 528.0 & 2.4 & 106.1 & 2.3 & 223 & 40.6 & 24.1 & 104 \\
\hline Overmature & 6.4 & 0.1 & 1.3 & 0.1 & 225 & 46.5 & 24.1 & 153 \\
\hline Total & 21472. & 100 & 4571.1 & 100 & 221 & 31.2 & 20.9 & 84 \\
\hline
\end{tabular}

Age amplitude of pine forest stands in North Dnieper Steppe covers 15 age classes (1 to 14 and 18) (Fig. 1).

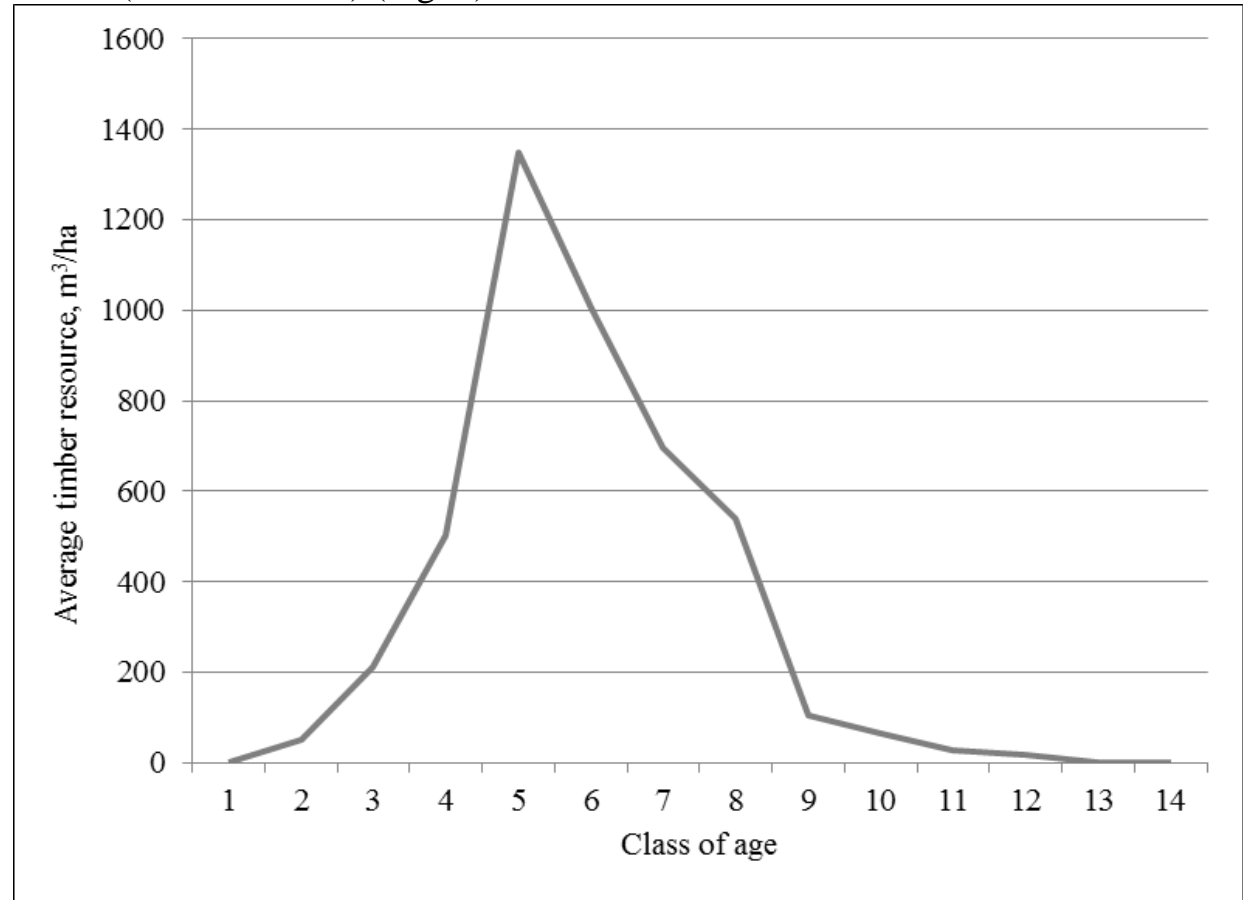

Figure 1. Growing stock of Scots pine stands depending on age classes

The largest area of Scots pine stands within studied territory was occupied by trees of III-VII age classes. Chare of such stands rises gradually from class III 
$(11.1 \%)$, reaches its maximum $(26.1 \%)$ in class $\mathrm{V}$, and further it goes into decline (10.5\%, class VII). The average growing stock per unit of area rise with increasing of the stand age ( 98.6 to $316.4 \mathrm{~m} 3 \cdot \mathrm{ha}-1$ ). Starting from age class IX, it has been fixed the relative minimum of the total area of overmature age category. As can be seen from the submitted graph, the total stock of timber varied proportionally with variation of stands area within different age classes (Fig. 1).

During the study, it has been grouped and analyzed the structure rate of this species in the stands within the Dnipropetrovsk region. It was established the predominance of pure forest stands with complete dominance of Scots pine on the total area 17578 ha (Fig. 2).

In mixed stands with the structure rate of pine 3-9, their area does not exceed $5 \%$ for each option. Robinia pseudoacacia, Quercus robur, Acer campestre and tataricum, Fraxinus viridis, Populus nigra, alba and canadensis serve as companion timber species in the Scots pine stands.

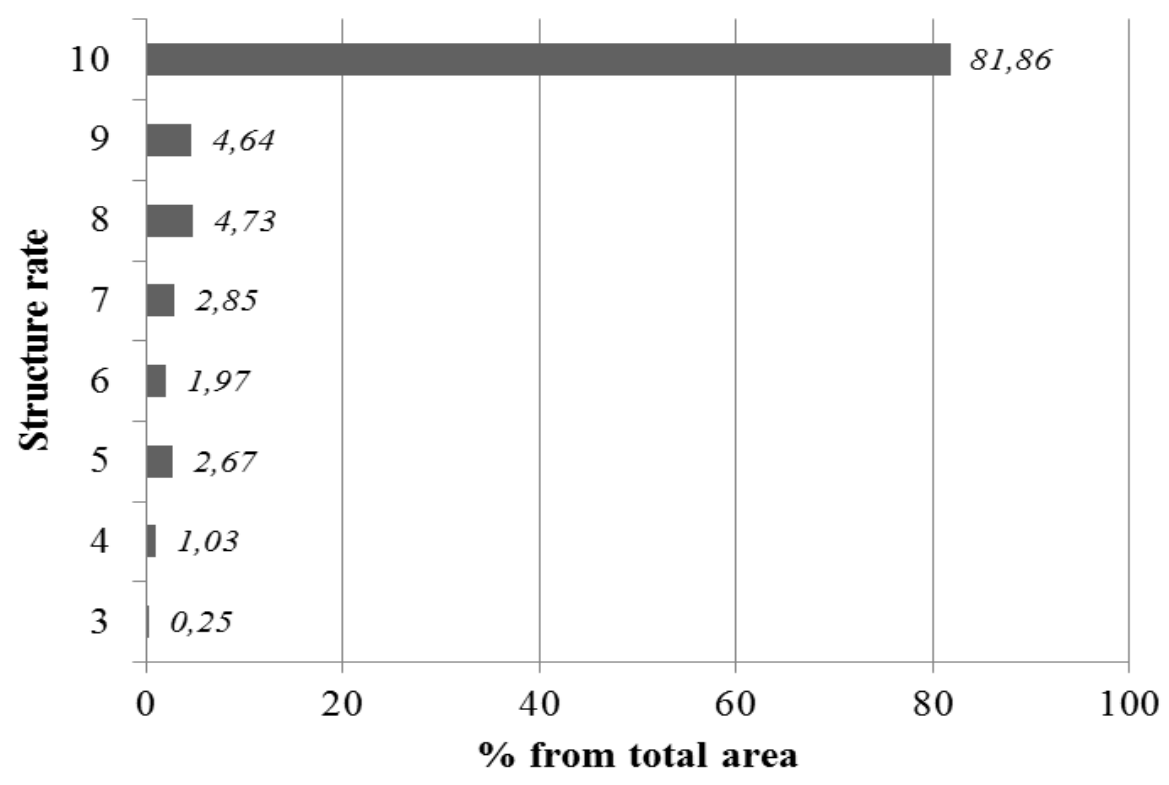

Figure 2. Distribution of the pine stands areas by structure rate, $\%$

By type of forest site, we have identified quite wide limits to Scots pine growth under condition of North Dnieper Steppe. Stands from Scots pine are formed on 17 types of edatopes: $\mathrm{A}_{0-3}, \mathrm{~B}_{1-4}, \mathrm{C}_{0-4}, \mathrm{D}_{0-3}$. By way of interpretation of forest site type data for Scots pine stands, it has been found that dry and mesic conditions dominated within the studied territories, and were 41.1 and $56.5 \%$, respectively; and $2 / 3$ of its total area was concentrated in mixed pine forests (Fig.3). 


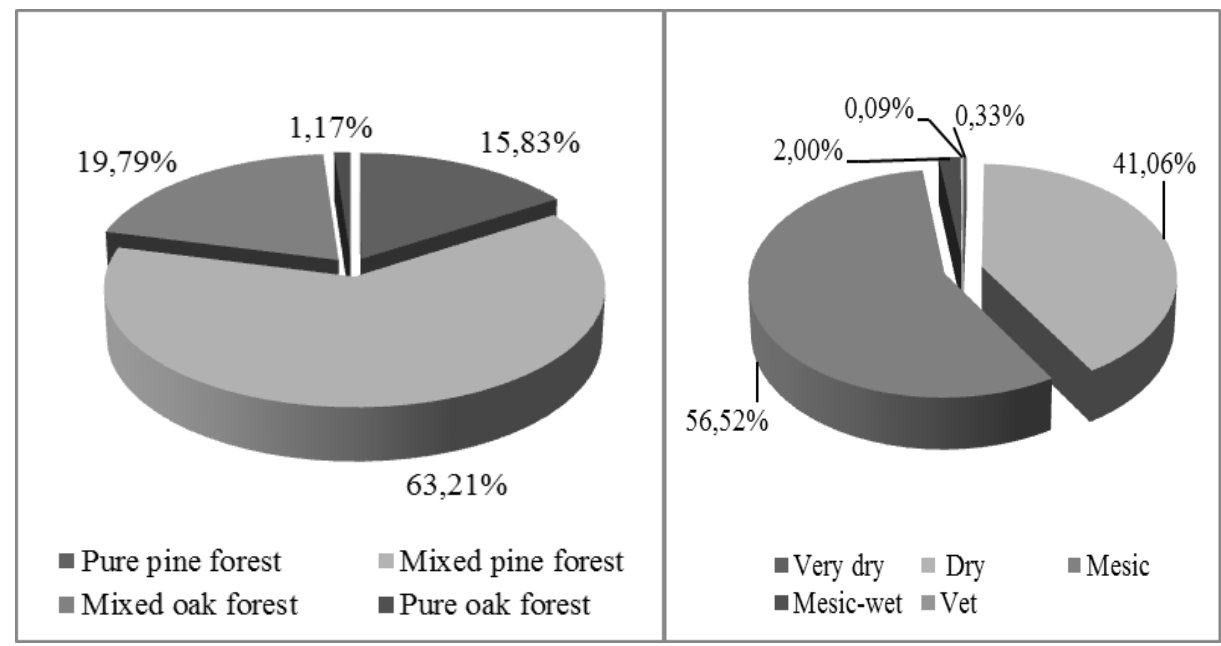

Figure 3. Distribution of the pine stands areas by trophogenic (A) and hygrogenic (B) ranges, \%

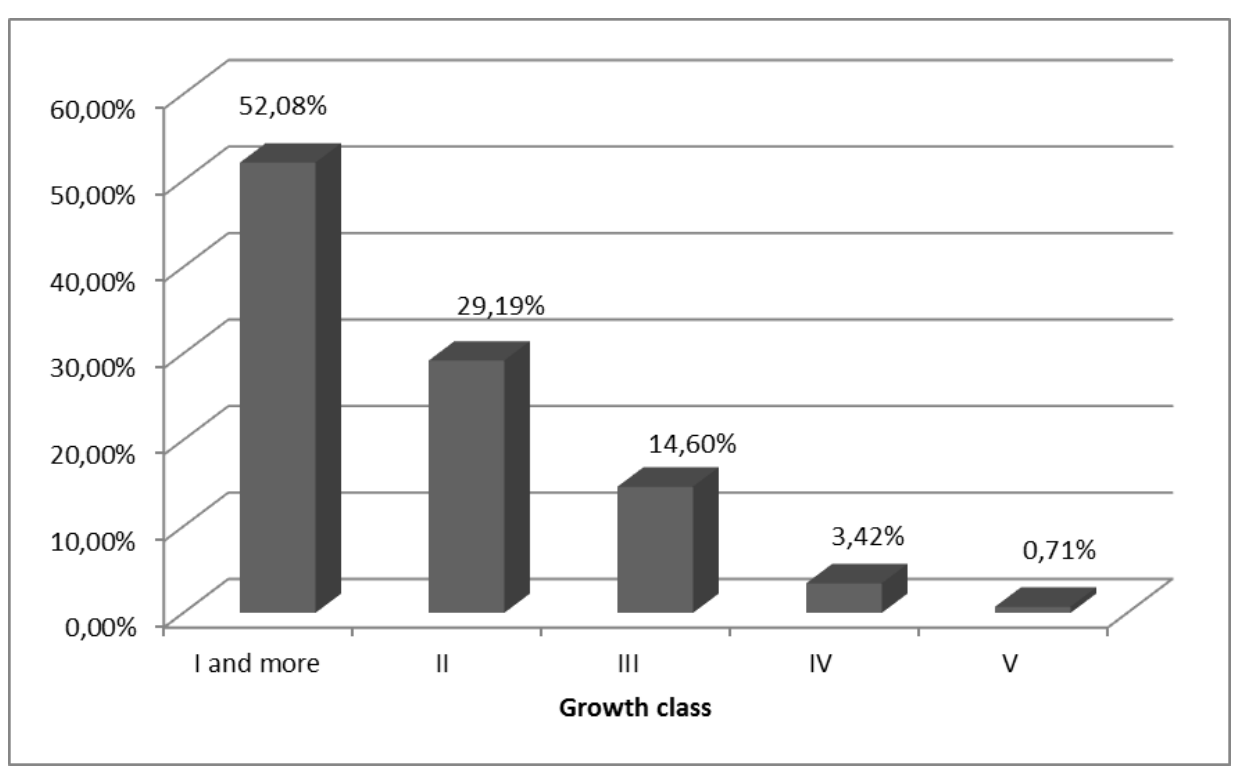

Figure 4. Distribution of the pine stands area by growth classes, $\%$

Shares of other 11 forest types, when Scots pine grows were less than $10.0 \%$ for each type. Within the other 25 forest types, the Scots pine stands had minimum areas 5.0\%. Taking into account the biological features of Scots pine, its light-demanding and middle demanding to the soil fertility, the prevailing conditions are quite favorable for such species growth.

Analysis of the areas distribution by forest capacity classes showed that the Scots pine stands are considered to be high-productive because this species 
grows in I and above forest capacity class, on the square 11183 hectares, according to Orlov (1911), accounting respectively for $52.1 \%$ (Fig. 4).

According to submitted data, the second largest area was occupied by pine stands of II forest capacity class, and the only $4.1 \%$ of area were occupied by poor stands of IV and V classes.

The degree of stocking is an important indicator of the stand condition because on the basis of this parameter it can be evaluated effectiveness of forest management aimed to improving the forest productivity. According to distribution of the Scots pine stands area by relative density, this species forms high-density stands on $\sim 1 / 2$ of total square (11778.6 ha); middle-density stands on 7569.6 ha, and poor and open stands occupied only $9.9 \%$ of the total area (Fig. $5)$.

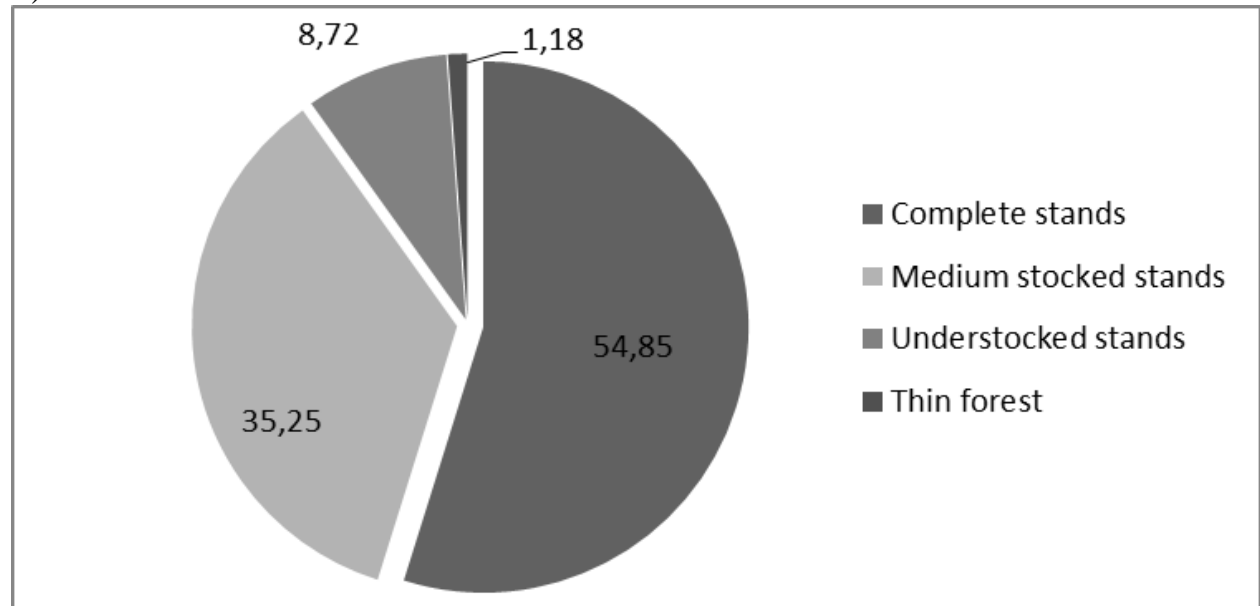

Figure 5. Distribution of the pine stands area on degree of stocking, $\%$

The average relative density of pine stands within the north dnieper steppe was quite high and amounted 0.71 . It largely depends on the age, significantly decreasing in overmature stands.

\section{CONCLUSIONS}

Area of Scots pine stands within North Dnieper Steppe is 21472 ha with the total growing stock $45711 \mathrm{~m} 3 \cdot \mathrm{ha}-1$. According to age structure, majority of the Scots pine stands within the studied region were middle-aged, with the greatest representation in the IV-VI age classes. Scots pine distribution by structure rate showed significant dominance of pure stands $(81.8 \%)$. Within North Dnieper Steppe, the Scots pine forests mainly formed under pine mixed forest site type, in dry and mesic hygrotopes. The largest area of the analyzed species was occupied by stands of II and above forest capacity classes. Stands of Scots pine in $\sim 1 / 2$ of the total square were high-density, whereas only $10 \%$ of the total pine forests areas were low-density and open. The results of this survey can 
be used to improve forestry activity in the pine stands within the studied region, in particular, when performing cleaning cutting, forest sanitation, and in determining the measures to create a highly productive, biologically sustainable plantations with appropriate regime of forestry activity.

\section{REFERENCES}

Alekseyev A.S. Monitoring of forest ecosystems. - St. Petersburg. Publishing house of Saint-Petersburg State Forest Engineering Academy, 2003. - 116 pp.

Anuchin N. P. Forest taxation. - Moscow: Forest Industry, 1982. - 552 pp.

Belgard A. L. Steppe Forestry. - Moscow: Forest industry, 1971. - 336 pp.

Bezrodnova O.V., Loza I.M., Nazarenko N.N. Herbage cover heterogeneity as indicator of ecology-phytocoenotical and biotopical diversity in oak forests // Bulletin of Kharkiv National University named V. N. Karazin. Series: Biology. Vol. 18 (No. 1079). -KNU. 2013. - 38-45.

Bormann, B. 1985. Air pollution and forests: an ecosystem perspective. BioSci. 35: 434441.

Casparsen, J.P. and S.W. Pacala. 2001. Successional diversity and forest ecosystem function. Ecol. Res. 16: 895-904.

FAO [Food and Agriculture Organization of the United Nations]. 1993. The challenge of sustainable forest management: What future for the worldís forests, FAO. Rome, Italy.

Gulchak V. P. Kravchuk F., Dudinets A.Y. et al. The fundamental principles of forestry organization and development in the Dnepropetrovsk oblast. - Irpin, 2011. - 129 pp.

Hensiruk S. A. Forests of Ukraine. - Kyiv: Nauk. Dumka, 1992. - 408 pp.

Vakuliuk P. G., V. I. Samoplavsky. Reforestation and afforestation in Ukraine. Kharkiv: Prapor, 2006. - 384 pp.

Lovinska V.M. The productivity of pine stands the Left Bank Pridneprovsk Steppe / Scientific Journal of the National University of Bioresources and Environmental Sciences of Ukraine. Series "Forestry and decorative gardening" - Kiev, 2014. Edition 198, Part 1 - P. 90-98.

Loza I., Nazarenko N. New Wetlands Formation in Subsidence Hollows of Western Donbass, Ukraine // J. Krecek and M. Haigh (eds.), Environmental Role of Wetlands in Headwaters. - NATO Science for Peace and Security Series, Springer, 2006. Printed in the Netherlands, 135-141.

Siryk A. A. Climat-forming role of artificial forest plantations in the Steppe of Ukraine / Forestry and agroforestry, 1991. - Vol. 83. - P. 7-12.

Sychev N. N. The growth characteristics of artificial plantations of Scots pine under the steppe condition. Access mode: http://conf.sfukras.ru/sites/mn2011/thesis/s14/s14_24.pdf

Sytnyk S., Lovinska V.M., Duminskiy G. Analysis of plantations with the participation of the main species forestforming state enterprise "Dnipropetrovsk forestry" / Scientific Journal of the NLTU. - Lviv, 2015. - Edition 25.1. - P. 92-96.

Scherer-Lorenzen, M., C. Körner and E.-D. Schulze (eds.). 2005. Forest diversity and function: temperate and boreal systems. Springer, Berlin 